\title{
ANALISIS COST VOLUME PROFIT DAN METODE ACTIVITY BASED COSTING UNTUK PENJUALAN BARANG BEKAS
}

\author{
Rubianto Pitoyo \\ Universitas Putra Indonesia YPTK Padang, Indonesia \\ e-mail: rubiantopitoyo@gmail.com
}

\begin{abstract}
This research target is to see the cost volume profit of scraps sales by using activity based costing method for the scrap of iron, scrap of cardboard, and scrap of plastic. In this research is used qualitative approach because policy of cost volume profit analysis, needing research having the character of exploration as a mean to know the effectivity and efficiency of applying the policy of cost/expense report which have been specified by management. Cost volume profit analysis represent the method to analyse the policy operate for and marketing to net profit, by virtue relation between variable cost, fixed cost, price sell per unit, and mount the output. Activity based costing is calculation system which correlating expense with the activity using resources and also adding the costs of resources to object cost like product, service or account of relocation intermediaries expense/cost by activity conducted for the object cost. The results showed that the operating profit of used goods sales generated using Activity Based Costing method is greater than if using conventional system.
\end{abstract}

Keywords: cost volume profit, activity based costing, scraps sales

\begin{abstract}
ASBTRAK
Tujuan penelitian ini adalah untuk melihat Cost Volume Profit penjualan barang bekas dengan menggunakan metode Activity Based Costing untuk barang bekas, yaitu besi bekas, kardus bekas, dan plastik bekas. Dalam penelitian ini digunakan pendekatan kualitatif karena kebijakan analisis biaya volume laba, memerlukan penelitian yang bersifat eksploratif dengan tujuan untuk mengetahui efektifitas dan efisiensi penerapan kebijakan pelaporan biaya yang telah ditetapkan oleh manajemen. Analisis Biaya Volume Laba merupakan metode untuk menganalisis kebijakan operasi dan pemasaran terhadap laba bersih, berdasarkan atas hubungan antara biaya variabel, biaya tetap, harga jual per unit, dan tingkat output. Activity Based Costing adalah sistem perhitungan yang mengaitkan biaya dengan aktivitas yang menggunakan sumber daya serta membebankan biaya-biaya sumber daya pada objek biaya seperti produk, jasa atau tempat penampungan biaya perantara berdasarkan aktivitas yang dilakukan untuk objek biaya tersebut. Hasil penelitian menunjukkan bahwa laba operasi penjualan barang bekas yang dihasilkan menggunakan metode Activity Based Costing lebih besar dibandingkan jika menggunakan sistem konvensional.
\end{abstract}

Kata kunci: biaya volume laba, activity based costing, penjualan barang bekas

Metode alokasi pendapatan secara Activity Based Costing (ABC) adalah sistem perhitungan yang baik perlu mengaitkan biaya dengan aktivitas yang menggunakan sumber daya serta membebankan biaya-biaya, sumber daya pada objek biaya seperti produk, jasa atau tempat 
penampungan biaya perantara berdasarkan aktivitas yang dilakukan untuk objek biaya tersebut. Dasar pemikiran pendekatan perhitungan biaya ini adalah bahwa produk atau jasa merupakan hasil dari aktivitas dan aktivitas tersebut menggunakan sumber daya yang menyebabkan timbulnya biaya (Blocher, 2007:227). Sementara itu metode alokasi pendapatan secara biaya volume laba atau CostVolume-Profit (CVP) adalah merupakan metode untuk menganalisis pengaruh keputusan operasi dan pemasaran terhadap laba bersih, berdasarkan atas hubungan antara biaya variabel, biaya tetap, harga jual per unit, dan tingkat output. Analisis biaya volume laba (CVP) didasarkan pada model eksplisit mengenai hubungan antara faktor biaya, pendapatan, dan laba, serta bagaimana perubahannya bila volume aktivitas berubah (Blocher, 2007:387).

Hasil pengamatan pada tahun 2012, laporan kegiatan usaha barang bekas tersebut menggunakan perhitungan pendapatannya secara konvensional yang artinya dalam penentuan harga pokok produksi, seluruh biaya produksi dibebankan sebagai harga pokok produksi, baik biaya yang berlaku variabel maupun tetap (Mulyadi, 1993:50). Seperti terlihat pada Tabel 1.

Tabel 1. Perhitungan Penjualan Barang Bekas Tahun 2012

\begin{tabular}{|c|c|c|c|}
\hline Uraian & Keterangan & $\begin{array}{c}\text { Debet } \\
\text { (Rp.) }\end{array}$ & $\begin{array}{l}\text { Kredit } \\
\text { (Rp.) }\end{array}$ \\
\hline Penjualan & & & 45.000 .000 \\
\hline \multirow[t]{6}{*}{ Pembelian } & Seng bekas $1 \mathrm{~kg}=\mathrm{Rp} 500 \times 3$ ton & 1.500 .000 & \\
\hline & Kardus $1 \mathrm{~kg}=\mathrm{Rp} 700 \times 13$ ton & 9.100 .000 & \\
\hline & Botol 4 bh/ kg= Rp $1.000 \times 1$ ton & 1.000 .000 & \\
\hline & Barang elektronik $1 \mathrm{~kg}=\mathrm{Rp} 1.200 \times 1$ ton & 1.200 .000 & \\
\hline & Barang plastik $1 \mathrm{~kg}=\mathrm{Rp} 1.000 \times 5$ ton & 5.000 .000 & \\
\hline & Besi $1 \mathrm{~kg}=\mathrm{Rp} 1.500 \times 7$ ton & 10.500 .000 & 28.300 .000 \\
\hline \multirow[t]{7}{*}{ Biaya operasi } & Biaya tetap : & & \\
\hline & -Sewa tanah & & 2.000 .000 \\
\hline & Biaya variabel : & & \\
\hline & -Sewa mobil & 1.600 .000 & \\
\hline & -Biaya buruh & 100.000 & \\
\hline & -Biaya sopir/BBM & 500.000 & \\
\hline & -Adm penjualan & 200.000 & 2.400 .000 \\
\hline \multicolumn{4}{|l|}{$\begin{array}{l}\text { Biaya non } \\
\text { operasi }\end{array}$} \\
\hline & Biaya pinjaman koperasi & 16.060 & \\
\hline & Lain-lain & 100.000 & 116.060 \\
\hline Laba bersih & & & 12.783 .940 \\
\hline
\end{tabular}

Sumber: Pengamatan dan penelitian, 2012.

Penelitian ini membatasi masalah yang akan dikaji untuk melihat analisis Biaya Volume Laba usaha barang bekas di Kabupaten Solok Selatan dengan menerapkan metode Activity Based Costing untuk barang bekas besi, barang bekas kardus, dan barang bekas plastik. Penelitian ini bermanfaat untuk pertimbangan dan pemilihan alokasi biaya operasi bagi bidang penjualan barang bekas dan sebagai catatan evaluasi dalam pengambilan keputusan untuk menentukan aktivitas operasi dan besaran laba bersih dari penjualan barang bekas. 
Dari hasil penelitian Marismiati (2011) dapat diketahui bahwa hasil perhitungan tarif rawat inap dengan menggunakan metode $A B C$, apabila dibandingkan dengan metode tradisional maka metode $A B C$ memberikan hasil yang lebih besar. Perbedaan yang terjadi antara tarif jasa rawat inap dengan menggunakan metode tradisional dan metode $A B C$, disebabkan karena pembebanan biaya overhead pada masing-masing produk. Sementara Tandiontong dan Lestari (2011) mendapatkan hasil penelitian sistem Activity Based Costing berperan dalam mengukur dan mengevaluasi tingkat pencapaian profitabilitas perusahaan, karena sistem Activity Based Costing memiliki tingkat keakuratan yang lebih baik dibandingkan dengan menggunakan metode kovensional dalam meningkatkan profitabilitas pengambilan keputusan. Sedangkan dari penelitian Anton (2012) diperoleh hasil penentuan harga pokok produk dengan metode Activity Based Costing dapat memberikan informasi biaya yang akurat dan relevan bagi pengambilan keputusan manajemen. Dengan informasi biaya tersebut menunjukkan manajemen dapat mempertimbangkan serangkaian pilihan strategi yang salah satunya adalah penentuan tarif produk, strategi pemasaran, peningkatan mutu dan efisiensi perusahaan.

\section{Perhitungan Biaya Berdasarkan Activity Based Costing}

Perhitungan biaya berdasarkan aktivitas pada dasarnya merupakan metode penentuan harga pokok produk (product costing) yang ditujukan untuk menyajikan informasi harga pokok produk secara cermat (accurate) bagi kepentingan manajemen, dengan mengukur secara cermat konsumsi sumber daya dalam setiap aktivitas yang digunakan untuk menghasilkan produk (Mulyadi, 1993:54).

Sistem perhitungan yang baik perlu mengaitkan biaya dengan aktivitas yang menggunakan sumber daya serta membebankan biaya-biaya, sumber daya pada objek biaya seperti produk, jasa atau tempat penampungan biaya perantara berdasarkan aktivitas yang dilakukan untuk objek biaya tersebut (Blocher, 2007:227). Perancangan sistem perhitungan biaya berdasarkan aktivitas memerlukan tiga tahap: 1) Mengidentifikasi biaya sumber daya dan aktivitas; 2) Membebankan biaya sumber daya ke aktivitas dan; 3) Membebankan biaya aktivitas ke objek biaya (Blocher, 2007:227).

\section{Analisis Cost Volume Profit}

Analisis biaya volume laba merupakan metode untuk menganalisis pengaruh keputusan operasi dan pemasaran terhadap laba bersih, berdasarkan atas hubungan antara biaya variabel, biaya tetap, harga jual per unit, dan tingkat output. Analisis biaya volume laba didasarkan pada model eksplisit mengenai hubungan antara faktor biaya, pendapatan, dan laba, serta bagaimana perubahannya bila volume aktivitas berubah (Blocher, 2007:387).

\section{Analisis Cost Volume Profit Untuk Perencanaan Titik Impas}

Analisis impas memberikan informasi tingkat penjualan minimum yang harus dicapai suatu usaha agar tidak mengalami kerugian. Dari analisis tersebut juga dapat diketahui sampai seberapa jauh volume penjualan yang direncanakan boleh turun, agar perusahaan tidak menderita kerugian (Mulyadi, 1993:260). Teori lain yang mengatakan bahwa titik impas yaitu titik ketika pendapatan sama dengan biaya total dan laba sama dengan nol (Blocher, 2005:392). Model analisis biaya volume laba diselesaikan dengan memasukan nilai-nilai $v$, $p$, dan $f, \mathrm{~N}$ ditetapkan sama dengan nol, kemudian hitung nilai $Q$. 


\section{Analisis Cost Volume Profit Untuk Activity Based Costing}

Analisis Cost-Volume-Profit untuk Activity Based Costing yaitu memberikan perhitungan biaya yang lebih akurat karena secara terpisah mengidentifikasi dan melurusi biaya-biaya tidak langsung ke produk dan bukan menggabungkan dalam kelompok biaya-biaya tetap seperti pendekatan volume. Model analisis Cost-Volume-Profit berbasis aktivitas menurut Mulyadi (1993:249) sebagai berikut:

$$
\text { Impas }=\frac{\text { Facility }- \text { sustaining cost }+ \text { product }- \text { sustaining cost }+ \text { batch }- \text { related cost }}{\text { Harga jual per unit }+ \text { unit }- \text { level costs per unit }}
$$

Penelitian ini adalah kualitatif dengan pendekatan evaluasi. Penelitian kualitatif adalah suatu pendekatan yang juga disebut pendekatan investigasi karena biasanya peneliti mengumpulkan data dengan cara bertatap muka langsung dan berinteraksi dengan orang-orang di tempat penelitian (McMillan \& Schumacher, 2003). Pendekatan evaluasi, merupakan suatu proses yang dilakukan dalam rangka menentukan kebijakan dengan terlebih dahulu mempertimbangkan nilai-nilai positif dan keuntungan suatu program, serta mempertimbangkan proses serta teknik yang telah digunakan untuk melakukan penilaian. Setiap kegiatan evaluasi biasanya dimaksudkan untuk mengembangkan kerangka berfikir dalam rangka pengambilan keputusan (Suharsimi, 2005:222). Analisis data dalam penelitian kualitatif, dilakukan mulai dari awal sampai sepanjang proses penelitian berjalan. Analisis data mengacu pada teknik yang telah dikembangkan Miles dan Huberman (1992) dalam Moeleong (1994) yakni menggunakan model interaktif dengan tiga prosedur; reduksi data, penyajian data, dan menarik kesimpulan atau verifikasi.

\section{HASIL DAN PEMBAHASAN}

Kegiatan pembelian dan penjualan barang bekas terdiri dari beberapa kegiatan. Pertama, usaha pengumpulan barang bekas ini pada dasarnya membeli dari para pemulung dengan berbagai jenis barang bekas berupa besi bekas padat Rp 3.300, besi bekas keropos Rp 2.000, besi bekas campur Rp 2.800, seng bekas Rp 1.500, plastik bekas Rp 300, kardus bekas Rp 300, alumunium (alma) Rp 1.200. Barang-barang bekas yang ditampung di Sapan Kecamatan Koto Parik Gadang Diateh Kabupaten Solok Selatan ini dijual ke beberapa kota. Diantaranya: Kota Padang, Kota Medan, dan bahkan langsung ke Jakarta. Barang bekas yang dijual berupa besi bekas dengan harga Rp $12.000 / \mathrm{Kg}$, plastik bekas Rp 6.000/Kg, kardus bekas Rp 6.000/Kg.

Untuk pengangkutan barang bekas ke kota-kota tersebut memakai truk fuso (kapasitas 12 Ton) dan truk colt diesel (kapasitas 8 Ton). Kapasitas muatan besi bekas sebanyak 5 ton dengan periode pengumpulannya selama 1 bulan, plastik bekas sebanyak $500 \mathrm{Kg}$ dengan periode pengumpulan selama satu minggu, kardus bekas sebanyak 24 ton dengan periode pengumpulan selama 1 bulan. 
Tabel 2. Kegiatan Pembelian dan Penjualan Barang Bekas pada Bulan November

\begin{tabular}{|c|c|c|c|c|c|}
\hline Uraian & Keterangan & Satuan & Harga satuan & & Jumlah \\
\hline \multirow[t]{5}{*}{ Penjualan } & Besi padu & 10 ton & $12.000 / \mathrm{Kg}$ & 120.000 .000 & \\
\hline & Besi kropos & 6 ton & $8.000 / \mathrm{Kg}$ & 48.000 .000 & \\
\hline & Kardus & 8 ton & $2.500 / \mathrm{Kg}$ & 20.000 .000 & \\
\hline & Plastik & 2 ton & $6.000 / \mathrm{Kg}$ & 12.000 .000 & \\
\hline & & & & & 200.000 .000 \\
\hline \multirow{5}{*}{ Pembelian } & Besi padat & 12 ton & $3.300 / \mathrm{Kg}$ & 36.000 .000 & \\
\hline & Besi keropos & 12 ton & $2.800 / \mathrm{Kg}$ & 26.000 .000 & \\
\hline & Kardus bekas & 24 ton & $1.000 / \mathrm{Kg}$ & 24.000 .000 & \\
\hline & Plastik & 2 ton & $3.000 / \mathrm{Kg}$ & 6.000 .000 & \\
\hline & & & & & $(92.000 .000)$ \\
\hline \multirow{5}{*}{$\begin{array}{l}\text { Laba Penjualan } \\
\text { Biaya Operasi }\end{array}$} & & & & & 108.000 .000 \\
\hline & Biaya tetap & & & & \\
\hline & $\begin{array}{l}\text { Sewa tempat } \\
\text { Biaya variabel }\end{array}$ & & 500.000 & & 500.000 \\
\hline & Gaji buruh & & 1.800 .000 & & 1.800 .000 \\
\hline & $\begin{array}{l}\text { Biaya } \\
\text { Transportasi }\end{array}$ & & 7.000 .000 & & 7.000 .000 \\
\hline Laba/rugi & & & & & 98.700 .000 \\
\hline
\end{tabular}

\section{Pengelompokan Biaya Berdasarkan Metode ABC}

Biaya tetap pada pengumpulan barang bekas ini adalah sewa tempat Rp 6.000.000/tahun. Sedangkan biaya variabel adalah gaji buruh sebesar Rp 1.800.000 dan biaya transportasi yang terdiri dari biaya transportasi ke Jakarta yaitu: biaya bensin (BBM) Rp 1.000.000, biaya retribusi Rp 65.000, biaya kapal Rp 800.000, uang makan Rp 500.000, dan biaya lain-lain Rp 635.000. biaya transportasi ke Padang diantaranya: biaya bensin $\mathrm{Rp} 200.000$, biaya retribusi $\mathrm{Rp} 65.000$, biaya lain-lain.

\section{Penjualan}

Penjualan barang-barang bekas yang dikumpulkan oleh pengusaha pengumpul barang bekas ini yaitunya ke Kota Padang, Kota Medan, dan Kota Jakarta. Untuk plastik bekas dijual ke Padang memakai mobil truk colt diesel yang berkapasitas 8 ton, dalam satu colt diesel tersebut hanya memuat plastik sebanyak $500 \mathrm{Kg}$ dengan harga jualnya Rp 6.000/Kg. Besi bekas di jual ke Jakarta menggunakan mobil truk fuso yang berkapasitas 12 ton. Untuk penjualan besi digabung antara besi bekas padat sebanyak 5 ton, besi bekas keropos 3 ton dan di tambah dengan kardus sebanyak 4 ton. Dengan harga perkilogramnya adalah: besi bekas padat Rp $12.000 / \mathrm{Kg}$, besi bekas keropos Rp $8.000 / \mathrm{Kg}$ dan kardus bekas Rp $2.500 / \mathrm{Kg}$.

\section{Pengangkutan}

Truk colt diesel berkapasitas muat 8 ton, yang berfungsi untuk mengantarkan plastik ke Padang. Kapasitas plastik yang dapat dimuat adalah sebanyak 1 ton. Biaya transportasi sebanyak Rp 500.000 yang berupa biaya BBM Rp 200.000, biaya retribusi Rp 65.000, biaya buruh Rp 450.000. Truk fuso digunakan untuk penjualan besi bekas padat, besi bekas keropos, dan kardus bekas yang berkapasitas 12 ton. Truk fuso yang digunakan untuk penjualan barang bekas ke Jakarta berupa besi bekas padat sebanyak 5 ton, besi bekas keropos sebanyak 3 ton dan kardus bekas sebanyak 4 ton. 
Biaya transportasi untuk penjualan barang bekas ke Jakarta sebanyak Rp 3.000 .000 diantaranya biaya bahan bakar minyak (BBM) sebanyak Rp 1.000.000, biaya buruh Rp 450.000, biaya kapal Rp 800.000, uang makan Rp 500.000, biaya retribusi Rp 65.000.

Tabel 3. Reduksi Data Berdasarkan Activity Based Costing

\begin{tabular}{|c|c|c|}
\hline Aktivitas & Jenis Biaya & Keterangan \\
\hline $\begin{array}{l}\text { Facility- } \\
\text { sustaining cost }\end{array}$ & - Sewa tempat & $\begin{array}{l}\text { Karena sewa tempat termasuk aktivitas untuk } \\
\text { menampung besar-kecilnya kapasitas dari barang } \\
\text { bekas yang dibeli. }\end{array}$ \\
\hline \multirow[t]{7}{*}{$\begin{array}{l}\text { Batch-related } \\
\text { cost }\end{array}$} & - Biaya BBM & $\begin{array}{l}\text { Biaya ini merupakan biaya transportasi untuk } \\
\text { pengangkutan barang yang akan dijual ke Padang dan } \\
\text { Jakarta. }\end{array}$ \\
\hline & - Uang sopir & $\begin{array}{l}\text { Merupakan biaya yang keluar dari aktivitas untuk } \\
\text { membayar supir pada saat pengangkutan barang ke } \\
\text { Jakarta. }\end{array}$ \\
\hline & - Biaya kapal & $\begin{array}{l}\text { Aktivitas yang dilakukan untuk mengirim barang ke } \\
\text { Jakarta dengan menggunakan kapal laut. }\end{array}$ \\
\hline & - Uang makan & $\begin{array}{l}\text { Biaya makan supir pada saat aktivitas pengangkutan } \\
\text { barang bekas ke Jakarta dan Padang. }\end{array}$ \\
\hline & - Biaya retribusi & $\begin{array}{l}\text { Biaya yang dikeluarkan untuk penimbangan barang } \\
\text { bekas saat aktivitas pengangkutan }\end{array}$ \\
\hline & - Uang rokok & $\begin{array}{l}\text { Biaya yang dikeluarkan pada saat pengangkutan } \\
\text { barang bekas ke Jakarta dan Padang. }\end{array}$ \\
\hline & - Biaya buruh & $\begin{array}{l}\text { Karena biaya buruh merupakan aktivitas dalam } \\
\text { pengangkutan barang ke truk. }\end{array}$ \\
\hline Unit-level cost & $\begin{array}{l}\text { - Harga pokok per } \\
\text { unit }\end{array}$ & $\begin{array}{l}\text { Karena merupakan aktivitas dalam menentukan harga } \\
\text { pokok produk per unitnya untuk setiap jenis produk. }\end{array}$ \\
\hline
\end{tabular}

Reduksi data sebagai proses pemilihan, pemusatan perhatian pada penyederhanaan, pengabstrakan, dan transformasi data kasar yang muncul dari catatan-catatan tertulis dilapangan. Data kasar yang diperoleh dilapangan kemudian dipilah-pilah kembali kedalam jenis-jenis biaya yang berhubungan/berkaitan dengan penelitian penulis. Setelah data dikelompokan kedalam jenis-jenis biaya maka diklasifikasikan lagi kedalam setiap aktivitas-aktivitas ABC (Activity Based Costing).

\section{Hasil Laporan Berdasarkan Metode ABC}

Penjualan besi bekas padat dilakukan dengan menggunakan truk fuso yang berkapasitas angkut 12 ton. Harga jual satuan di Jakarta Rp 12.000/Kg dengan total penjualan Rp 240.000.000/ sekali angkut. Pembelian yang dilakukan untuk besi bekas padat secara tunai dengan harga Rp 3.300/Kg. Waktu yang dibutuhkan untuk mengumpulkan 12 ton adalah selama satu bulan, penjualan bisa dilakukan selama satu kali dalam satu bulan. Biaya yang terjadi untuk memproses pengangkutan sebesar Rp 3.950.000/satu kali angkut. Dari penjualan besi padu diatas didapatkan laba sebesar Rp 196.450.000 untuk satu kali penjualan dalam satu bulan. 
Tabel 4. Kalkulasi Metode ABC untuk Besi Bekas Padat

\begin{tabular}{|c|c|c|c|c|}
\hline Keterangan & $\begin{array}{l}\text { Harga satuan } \\
\text { (Rp.) }\end{array}$ & Unit & $\begin{array}{l}\text { Jumlah } \\
\text { (Rp.) }\end{array}$ & $\begin{array}{l}\text { Harga per } \\
\text { unit (Rp.) }\end{array}$ \\
\hline Pendapatan penjualan & $12.000 / \mathrm{Kg}$ & 12 ton & 240.000 .000 & \\
\hline Biaya penuh untuk: & & & & \\
\hline Biaya produksi: & & & & \\
\hline $\begin{array}{l}\text { - Harga beli } \\
\text { - Batch-related activity costs }\end{array}$ & $3.300 / \mathrm{Kg}$ & $12.000 \mathrm{Kg}$ & $(39.600 .000)$ & $3.300 / \mathrm{Kg}$ \\
\hline - Biaya BBM & 1.000 .000 & & & \\
\hline - Uang supir & 450.000 & & & \\
\hline - Biaya kapal & 800.000 & & & \\
\hline - Uang makan & 500.000 & & & \\
\hline - Biaya retribusi & 65.000 & & & \\
\hline - Uang rokok & 185.000 & & & \\
\hline - Biaya buruh & 450.000 & & & \\
\hline & & & $(3.450 .000)$ & 287,5 \\
\hline $\begin{array}{l}\text { - Biaya berkaitan dengan } \\
\text { aktivitas tempat }\end{array}$ & & & & \\
\hline $\begin{array}{l}\text { - Sewa tempat } \\
\text { - Biaya satuan tingkat aktivitas }\end{array}$ & 500.000 & 1 bulan & $\begin{array}{r}(500.000) \\
(43.550 .000)\end{array}$ & $\begin{array}{r}41,7 \\
3.629,2\end{array}$ \\
\hline Laba (rugi) per produk & & & 196.450 .000 & \\
\hline
\end{tabular}

Titik Impas Untuk Besi Bekas Padat

$$
\begin{aligned}
& \text { Titik impas }=\frac{\text { Biaya berkaitan dengan aktivitas tempat }+ \text { Batch Level Activity }}{\text { Harga jual }- \text { Unit Level Cost }} \\
& \text { Titik impas: } \frac{500.000+3.450 .000}{12.000-3.629,2}
\end{aligned}
$$

Penjualan besi bekas keropos dilakukan dengan menggunakan truk fuso yang berkapasitas angkut 12 ton. Harga jual satuan di Jakarta Rp 8.000/Kg dengan total penjualan Rp 96.000.000/ sekali angkut. Pembelian yang dilakukan untuk besi bekas keropos secara tunai dengan harga Rp $2.800 / \mathrm{Kg}$. Waktu yang dibutuhkan untuk mengumpulkan 12 ton adalah selama satu bulan, penjualan bisa dilakukan selama satu kali dalam satu bulan. Biaya yang terjadi untuk memproses pengangkutan sebesar Rp 3.950.000/satu kali angkut. Dari penjualan besi bekas keropos di atas didapatkan laba sebesar Rp 58.450.000 untuk satu kali penjualan dalam satu bulan. 
Tabel 5. Kalkulasi Metode ABC untuk Besi Bekas Keropos

\begin{tabular}{|c|c|c|c|c|}
\hline Keterangan & $\begin{array}{l}\text { Harga satuan } \\
(\mathrm{Rp} .)\end{array}$ & Unit & $\begin{array}{l}\text { Jumlah } \\
\text { (Rp.) }\end{array}$ & $\begin{array}{l}\text { Harga per } \\
\text { unit (Rp.) }\end{array}$ \\
\hline $\begin{array}{l}\text { Pendapatan penjualan } \\
\text { Biava penuh untuk: }\end{array}$ & $8.000 / \mathrm{Kg}$ & 12 ton & 96.000 .000 & \\
\hline Biaya produksi: & & & & \\
\hline - Harga beli & $2.800 / \mathrm{Kg}$ & $12.000 \mathrm{Kg}$ & ( 33.600 .000$)$ & $2.800 / \mathrm{Kg}$ \\
\hline Batch-related activity costs & & & & \\
\hline - Biaya BBM & 1.000 .000 & & & \\
\hline - Uang supir & 450.000 & & & \\
\hline - Biaya kapal & 800.000 & & & \\
\hline - Uang makan & 500.000 & & & \\
\hline - Biaya retribusi & 65.000 & & & \\
\hline - Uang rokok & 185.000 & & & \\
\hline - Biaya buruh & 450.000 & & & \\
\hline $\begin{array}{l}\text { Biaya berkaitan dengan aktivitas } \\
\text { tempat }\end{array}$ & & & (3.450.000) & 287,5 \\
\hline - Sewa tempat & 500.000 & 1 bulan & $(500.000)$ & 41,7 \\
\hline Biaya satuan tingkat aktivitas & & & $(37.550 .000)$ & $3.129,2$ \\
\hline Laba (rugi) per produk & & & 58.450 .000 & \\
\hline
\end{tabular}

Titik Impas Untuk Besi Bekas Keropos

$$
\begin{aligned}
\text { Titik impas } & =\frac{\text { Biaya berkaitan dengan aktivitas tempat }+ \text { Batch Level Activity }}{\text { Harga jual }- \text { Unit Level Cost }} \\
\text { Titik impas } & =\frac{500.000+3.450 .000}{8.000-3.129,2} \\
& =\frac{3.950 .000}{4870,8} \\
& =810,9 \mathrm{Kg}
\end{aligned}
$$

Penjualan kardus bekas dilakukan dengan menggunakan truk fuso yang berkapasitas angkut 12 ton. Dari kapasitas truk fuso yang 12 ton hanya bisa memuat kardus bekas sebanyak 8 ton karena kapasitas volume truk fuso tersebut untuk ukuran kardus hanya bisa menampung sebanyak 8 ton. Harga jual satuan di Jakarta Rp 2.500/Kg dengan total penjualan Rp 20.000.000/sekali angkut. Pembelian yang dilakukan untuk kardus bekas secara tunai dengan harga Rp 1.000/Kg. Waktu yang dibutuhkan untuk mengumpulkan 8 ton adalah selama satu minggu, penjualan bisa dilakukan selama dua kali dalam satu bulan dikarenakan waktu yang dibutuhkan untuk melakukan penjualan selama 12 hari. Biaya yang terjadi untuk memproses pengangkutan sebesar Rp 3.950.000/satu kali angkut. Dari penjualan kardus bekas diatas didapatkan laba sebesar Rp 8.050.000 untuk satu kali penjualan. 
Tabel 6. Kalkulasi Metode ABC untuk Kardus Bekas

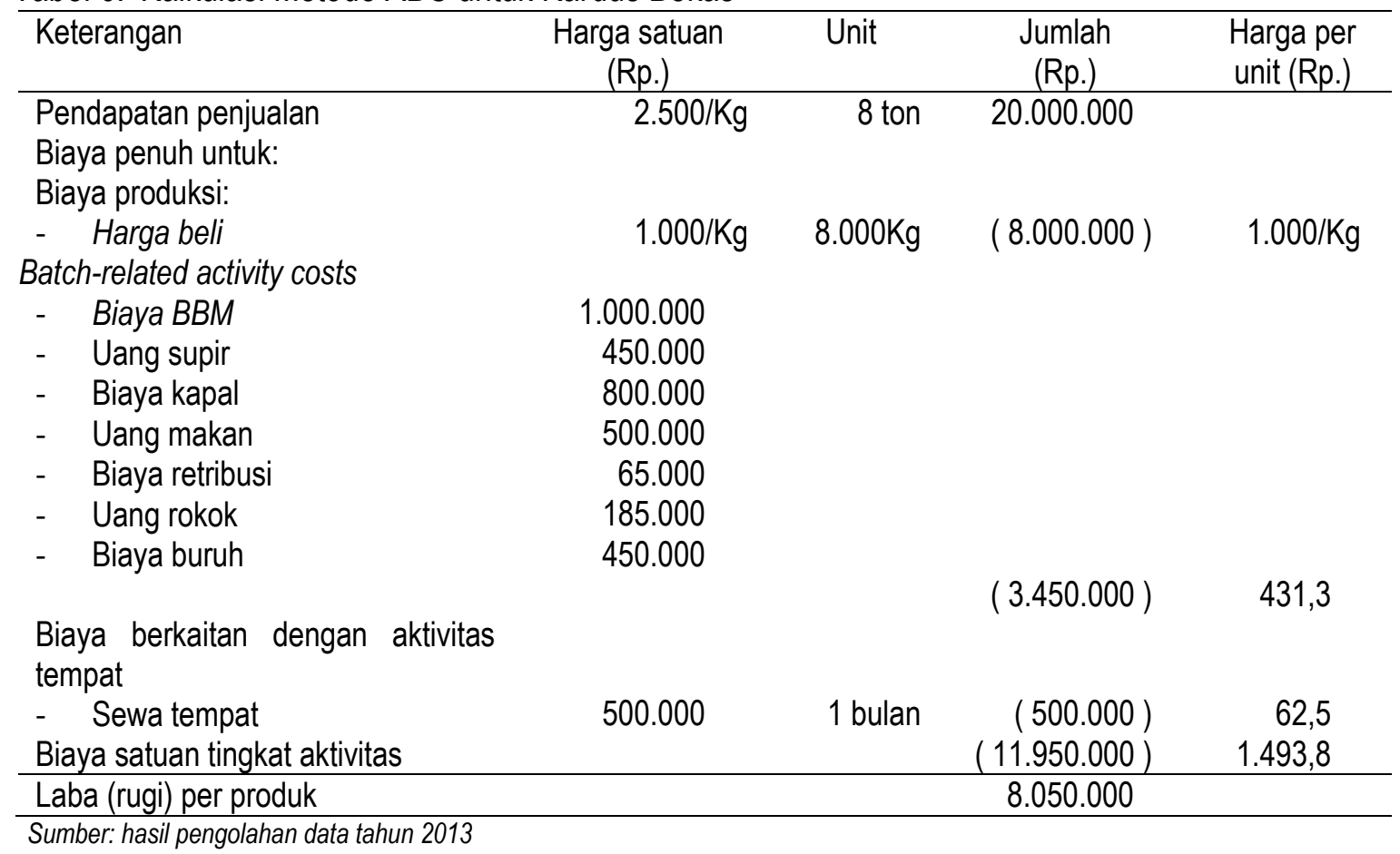

Titik Impas Untuk Kardus Bekas

$$
\begin{aligned}
\text { Titik impas } & =\frac{\text { Biaya berkaitan dengan aktivitas tempat }+ \text { Batch Level Activity }}{\text { Harga jual }- \text { Unit Level Cost }} \\
\text { Titik impas } & =\frac{500.000+3.450 .000}{2.500-1.493,8} \\
& =\frac{3.950 .000}{1.006,2} \\
& =3.925,6 \mathrm{Kg}
\end{aligned}
$$

Penjualan plastik bekas dilakukan dengan menggunakan truk colt diesel yang berkapasitas angkut 8 ton. Dari kapasitas truk colt diesel yang 8 ton hanya bisa memuat plastik bekas sebanyak 1 ton dikarenakan kapasitas volume truk colt diesel tersebut untuk ukuran plastik hanya bisa menampung sebanyak 1 ton. Harga jual satuan di Padang Rp 6.000/Kg dengan total penjualan Rp $6.000 .000 /$ sekali angkut. Pembelian yang dilakukan untuk plastik bekas secara tunai dengan harga Rp 3.000/Kg. Waktu yang dibutuhkan untuk mengumpulkan 1 ton adalah selama satu minggu, penjualan dapat dilakukan selama empat kali dalam satu bulan. Biaya yang terjadi untuk memproses pengangkutan adalah sebesar Rp 1.450.000/satu kali angkut. Dari kegiatan penjualan plastik bekas di atas didapatkan laba sebesar Rp 1.550 .000 untuk satu kali penjualan. 
Tabel 7. Kalkulasi Metode ABC untuk Plastik Bekas

\begin{tabular}{|c|c|c|c|c|}
\hline Keterangan & $\begin{array}{l}\text { Harga satuan } \\
\text { (Rp.) }\end{array}$ & Unit & $\begin{array}{l}\text { Jumlah } \\
\text { (Rp.) }\end{array}$ & $\begin{array}{l}\text { Harga per } \\
\text { unit (Rp.) }\end{array}$ \\
\hline $\begin{array}{l}\text { Pendapatan penjualan } \\
\text { Biaya penuh untuk: }\end{array}$ & $6.000 / \mathrm{Kg}$ & 1 ton & 6.000 .000 & \\
\hline Biaya produksi: & & & & \\
\hline - Harga beli & $3.000 / \mathrm{Kg}$ & 1 ton & (3.000.000) & $\mathrm{Rp} 3.000 / \mathrm{Kg}$ \\
\hline Batch-related activity costs & & & & \\
\hline Biaya BBM & 200.000 & & & \\
\hline - Uang makan & 100.000 & & & \\
\hline - Biaya retribusi & 65.000 & & & \\
\hline - Uang rokok & 135.000 & & & \\
\hline - Biaya buruh & 450.000 & & & \\
\hline $\begin{array}{l}\text { Biaya berkaitan dengan aktivitas } \\
\text { tempat }\end{array}$ & & & $(950.000)$ & Rp 950 \\
\hline $\begin{array}{l}\text { - Sewa tempat } \\
\text { Biaya satuan tingkat aktivitas }\end{array}$ & 500.000 & 1 bulan & $\begin{array}{r}(500.000) \\
(4.450 .000)\end{array}$ & $\begin{array}{r}\operatorname{Rp} 500 \\
\operatorname{Rp} 4.450 \\
\end{array}$ \\
\hline Laba (rugi) per produk & & & 1.550 .000 & \\
\hline
\end{tabular}

Titik Impas Untuk Plastik Bekas

$$
\begin{aligned}
\text { Titik impas } & =\frac{\text { Biaya berkaitan dengan aktivitas tempat }+ \text { Batch Level Activity }}{\text { Harga jual }- \text { Unit Level Cost }} \\
\text { Titik impas } & =\frac{950.000+500.000}{6.000-4.450} \\
& =\frac{1.450 .000}{1.550} \\
& =935,5 \mathrm{Kg}
\end{aligned}
$$

\section{PENUTUP}

Berdasarkan penelitian dan hasil pembahasan yang dilakukan mengenai penerapan metode Activity Based Costing pada penjualan barang bekas diambil kesimpulan bahwa volume penjualan barang bekas ke Jakarta dan Padang dengan menggunakan aktivitas penjualan secara konvensional sebanyak 26 ton, sedangkan dengan menggunakan aktivitas penjualan secara Activity Based Costing sebanyak 33 ton. Dari peningkatan volume penjualan tersebut maka pengusaha pengumpul barang bekas perlu merubah aktivitas penjualannya menggunakan Activity Based Costing. Untuk besi bekas padat, besi bekas kropos, kardus bekas penjualannya ke Jakarta dengan biaya sebesar Rp 3.500.000/satu kali pengangkutan. Kardus bekas lebih baik penjualannya ke Padang karena biaya yang dikeluarkan lebih efisien dan pengangkutannya bisa tiga kali dalam satu bulan daripada ke Jakarta yang cuma dua kali. Laba yang diperoleh dari penjualan ke Padang untuk besi bekas padat Rp 4.580/Kg dan Jakarta Rp 7.409/Kg, untuk kardus Rp 1.213/Kg (Padang) dan Rp 1.063/Kg 
(Jakarta). Untuk besi bekas lebih baik menjual ke Jakarta sedangkan untuk kardus bekas lebih baik menjual ke Padang karena labanya cukup besar dibandingkan dengan Jakarta.

\section{REFERENSI}

Anton. (2012). Analisis Penentuan Harga Pokok Produksi Menggunakan Metode Activity Based Costing (Studi Kasus Pada PT. Bintang Semarang). Majalah IImiah INFORMATIKA, Vol. 3 No. 3, Sept. 2012.

Blocher. (2007). Manajemen Biaya, Penerapan Strategi. Edisi tiga, Jakarta. Penerbit Salemba Empat.

Marismiati. (2011). Peranan Metode Activity-Based Costing System Dalam Menentukan Harga. Jurnal Ekonomi dan Informasi Akuntansi, Jenious, Vol.1, No. 1.

Mathius T \& Ardisa Lestari. (2011). Peranan Activity-Based Costing System Dalam Perhitungan Harga Pokok Terhadap Peningkatan Profitabilitas Perusahaan (Studi Kasus pada PT Retno Muda Pelumas Prima Tegal). Akurat Jurnal Ilmiah Akuntansi Nomor 05 Tahun ke-2 MeiAgustus 2011.

Matz, Adolph. (1995). Akuntansi Biaya. Perencanaan dan Pengendalian. Edisi kesembilan. Jakarta. Erlangga.

McMillan \& Schumacher. (2003). Metodologi Penelitian Kualitatif. Bandung. PT. Remaja Rosdi karya.

Miles \& Huberman. (1992). Qualitatif Data Analisis A Shource Book Of A Nem Methods. Sage

Pulicion, Beverlyitills, London, New Delhi, terjemahan oleh ljetjip Rohendri Rohidi, Jakarta.

Mulyadi. (1993). Akuntansi Manajemen. Konsep, Manfaat, Dan Rekayasa. Edisi kedua, Yogyakarta. Sekolah Tinggi Ilmu Ekonomi YKPN.

Suharsimi Arikunto. (2005). Manajemen Penelitian. Edisi Revisi. Rineka Cipta. 